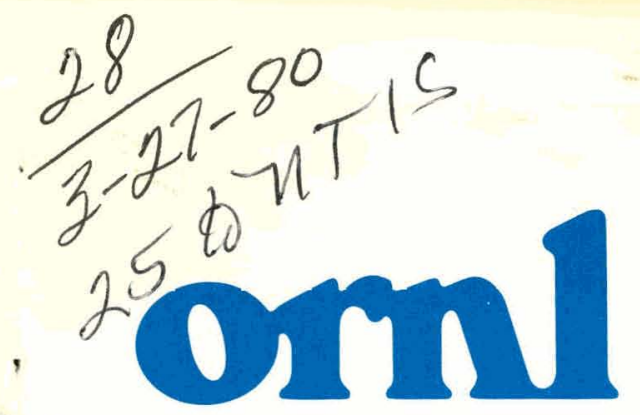

OAK RIDGE NATIONAL LABORATORY CARBIDE

\title{
Browns Ferry Waste Heat Greenhouse Environmental Control System Design
}

\author{
M. Olszewski \\ T. K. Stovall \\ N. G. Hicks
}

R. S. Pile

E. R. Burns

E. L. Waddell, Jr.

OPERATED BY

UNION CARBIDE CORPORATION FOR THE UNITED STATES DEPARTMENT OF ENERGY 


\section{DISCLAIMER}

This report was prepared as an account of work sponsored by an agency of the United States Government. Neither the United States Government nor any agency Thereof, nor any of their employees, makes any warranty, express or implied, or assumes any legal liability or responsibility for the accuracy, completeness, or usefulness of any information, apparatus, product, or process disclosed, or represents that its use would not infringe privately owned rights. Reference herein to any specific commercial product, process, or service by trade name, trademark, manufacturer, or otherwise does not necessarily constitute or imply its endorsement, recommendation, or favoring by the United States Government or any agency thereof. The views and opinions of authors expressed herein do not necessarily state or reflect those of the United States Government or any agency thereof. 


\section{DISCLAIMER}

Portions of this document may be illegible in electronic image products. Images are produced from the best available original document. 


\section{Printed in the United States of America. Available from National Technical Information Service \\ U.S. Department of Commerce \\ 5285 Port Royal Road, Springfield, Virginia 22161 \\ NTIS price codes-Printed Copy: A03 Microfiche A01}

This report was prepared as an account of work sponsored by an agency of the United States Government. Neither the United States Government nor any agency thereof, nor any of their employees, makes any warranty, express or implied, or assumes any legal liability or responsibility for the accuracy, completeness, or usefulness of any information, apparatus, product, or process disclosed, or represents that its use would not infringe privately owned rights. Reference herein to any specific commercial product, process, or service by trade name, trademark, manufacturer, or otherwise, does not necessarily constitute or imply its endorsement, recommendation, or favoring by the United States Government or any agency thereof. The views and opinions of authors expressed herein do not necessarily state or reflect those of the United States Government or any agency thereof. 
Contract No. W-7405-eng-26

Engineering Technology Division

BROWNS FERRY WASTE HEAT GREENHOUSE

ENVIRONMENTAL CONTROL SYSTEM DESIGN

M. O1szewski and T. K. Stoval1, Oak Ridge National Laboratory;

N. G. Hicks, Environmental Research Laboratory;

R. S. Pile, E. R. Burns, and E. L. Waddell, Jr., Tennessee Valley Authority

Date Published: March 1980

The facility was constructed and operated by the Tennessee Valley Authority at the Browns Ferry Nuclear Plant. The greenhouse design was a cooperative effort of TVA, the Oak Ridge National Laboratory, and the Environmental Research Laboratory at the University of Arizona.

\author{
Prepared by the \\ OAK RIDGE NATIONAL LABORATORY \\ nak Ridge, Tennessee 37830 \\ operated by \\ UNION CARBIDE CORPORATION \\ for the \\ DEPARTMENT OF ENERGY
}

This book was prepared as an account of work sponsored by an agency of the United States Government. Neither the United States Government nor any agency thereof, nor any of their emplovees. makes any ogmplomers, ars represents that its use would not intringe privately owned rights Reterence herein to eny spec,fic comanercial uroduct, process, or service by trade name, trademark, manufacturer, or otherwise, does nol necessarily constitute or imply its endorsement, recommendation, or favoring by tho United States Government or any agency thereof. The views and apinions of authors expressed herein do not 


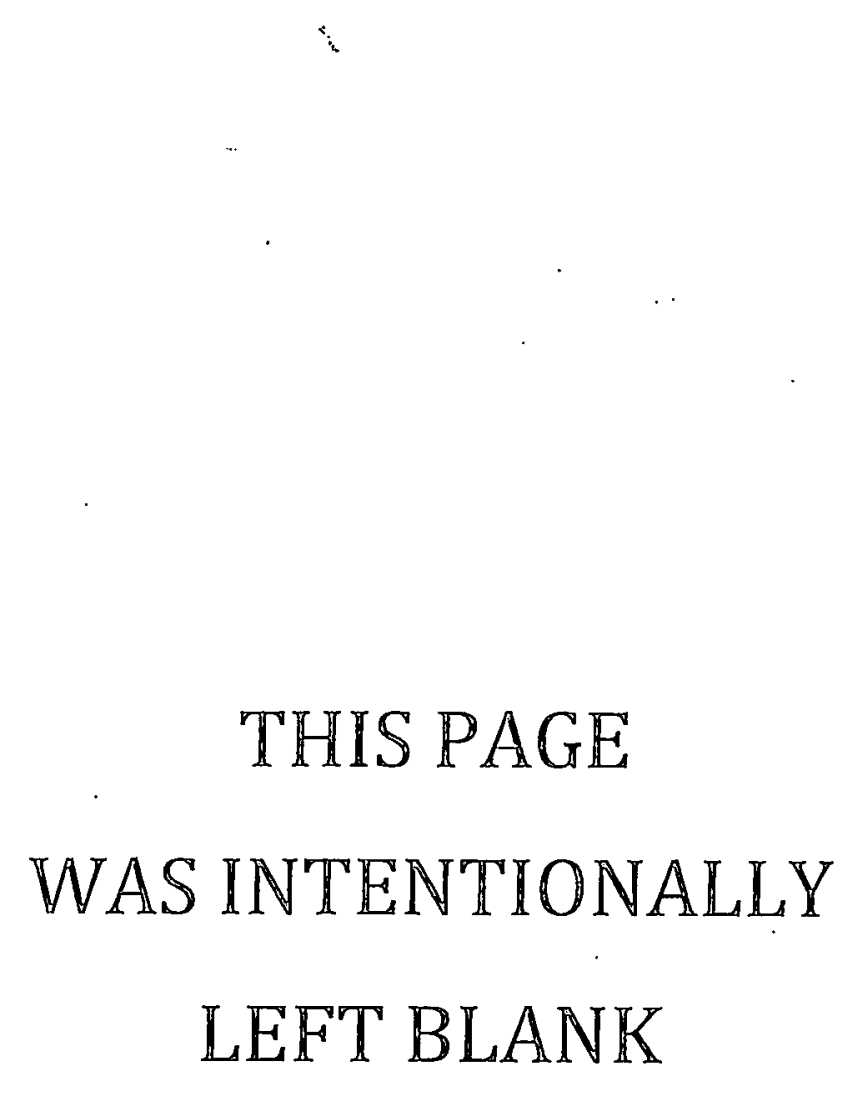


CONTENTS

Page

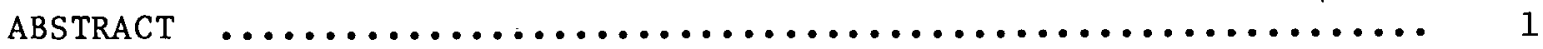

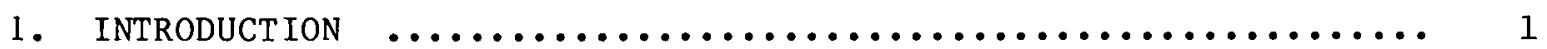

2. DESIGN CONSIDERATIONS FOR THE BROWNS FERRY GREENHOUSE $\ldots \ldots \ldots .5$

2.1 General Considerations and Design Assumptions ......... 5

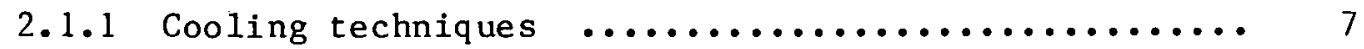

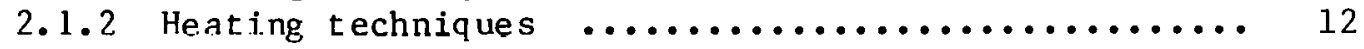

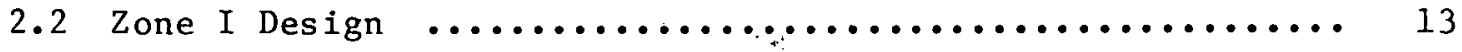

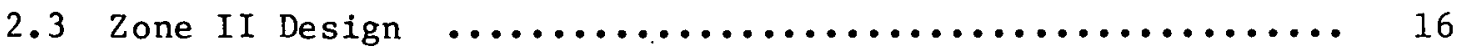

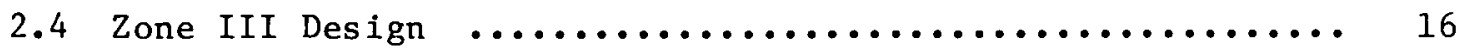

3. ENVIRONMENTAL CONTROL SYSTEM PERFORMANCE $\ldots \ldots \ldots \ldots \ldots \ldots \ldots \ldots$

3.1 Initial Testing Period ....................... 19

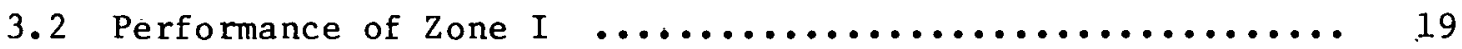

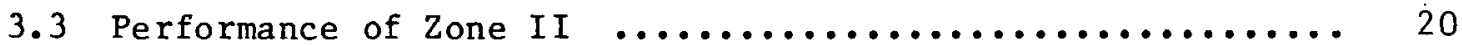

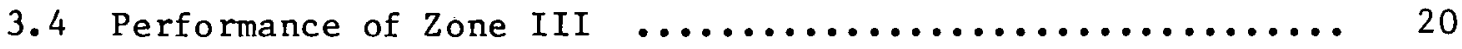

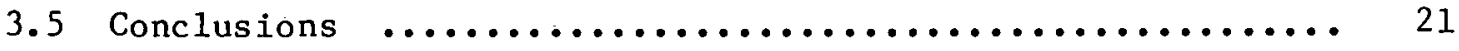

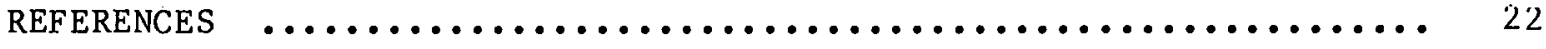


BROWNS FERRY WASTE HEAT GREENHOUSE

ENVIRONMENTAL CONTROL SYSTEM DESIGN
M. OIszewski
R. S. Pile ${ }^{\dagger}$
T. K. Stoval1
N. G. Hicks*
E. R. Burns ${ }^{\dagger}$
E. L. Waddell, $\mathrm{Jr}$. $^{\dagger}$

\section{ABSTRACT}

Oak Ridge National Laboratory, Tennessee Valley Authority (TVA), and Environmental Research Laboratory cooperated on the design of an experimental greenhouse located at TVA's Browns Ferry Nuclear Generating Station. Two greenhouse zones are heated by waste heat from the plant's condenser effluent. For comparison, a third greenhouse zone is heated conventionally (fossil-fueled burners) as a control. Design specifics for each of the three zones and a qualitative operating evaluation are included in this report.

\section{INTRODUCTION}

Large quantities of low-grade heat are produced as by-products of . both fossil-fired and nuclear-fueled electric generating stations and are simply discharged to the condenser cooling water. About $60 \%$ of the energy from fossil-fired plants and $65 \%$ from nuclear-fueled plants are discharged as 1 ow-grade waste heat, constituting $\sim 15 \%[\sim 12.6 \mathrm{GJ}$ (12 quads)] of the total energy consumption in the United States.

Although large amounts of energy are contained in waste heat, the availability and usefulness of this energy are quite limited. Waste heat temperatures are normally only about 5 to $20^{\circ} \mathrm{C}$ ( 9 to $36^{\circ} \mathrm{F}$ ) above incoming cooling water temperatures, with winter waste heat temperatures normally ranging from 14 to $40^{\circ} \mathrm{C}$ ( 57 to $104^{\circ} \mathrm{F}$ ).

Many uses have been proposcd for power plant waste heat. The most promising uses are for direct heating in energy-intensive systems with low-grade heat requirements. Many agricultural and aquacultural systems have thermal requirements meeting these criteria. Greenhouse production

\footnotetext{
*Environmental Research Laboratory.

†Tennessee Valley Authority.
} 
systems are among the most promising users of waste heat, primarily because of the large heating-energy requirements.

For several years, the Tennessee Valley Authority (TVA), Oak Ridge National Laboratory (ORNL), and Environmental Research Laboratory (ERL) of the University of Arizona have been concerned with developing greenhouse production systems capable of using waste heat. The use of direct-contact heat-exchange systems using evaporative pads as a primary heat exchanger has been investigated by each of these organizations. These investigations preceded the joint Browns Ferry Greenhouse design effort.

TVA has been involved in research and development of potential agricultural uses of power plant waste heat for several years. As a part of this effort, TVA began evaluating vegetable crop production in humid environments in the late 1960s. Results of these tests led to the construction of a pilot-scale waste heat greenhouse at Muscle Shoals, Alabama, which has been in operation since 1973. The greenhouse environmental. control system was designed cooperatively by TVA and ORNL. Aspen pads were initially used but were replaced with CELdek* in 1975 after tests conducted at ORNL indicated more desirable performance with CELdek.l

I'he Muscle Shoals facility uses simulated waste heat in a combination evaporative-pad and finned-tube heat-exchange system to achieve environmental control. The amount of heating is controlled by modulating the amount of air that is recirculated within the greenhouse with $100 \%$ air recirculation during maximum heating. The performance of the environmental control system has been characterized over a wide range of operating conditions, and the system has successfully maintained winter greenhouse temperatures of $14^{\circ} \mathrm{C}\left(58^{\circ} \mathrm{F}\right)$ with water temperatures as low as $20^{\circ} \mathrm{C}\left(68^{\circ} \mathrm{F}\right)$. The compatibility of several vegetable and ornamental greenhouse crops with the resulting high humidity has alsn hepn examined with recpect to crop productivity and specific production problems. Management schemes have been developed for environmental control system operation and successful crop production.

ORNL began investigations on using reject heat for greenhouse applications in 1968. This effort began with analytical studies investigating

\footnotetext{
${ }^{*} \mathrm{~A}$ registered trademark of the Munters Corporation.
} 
the engineering detalls and technical feastbility of the evaporative-pad greenhouse concept. These studies then led to the design of a greenhouse environmental control system for experimental testing.

The system examined for heating and cooling greenhouses is illustrated in Fig. 1. A conventional pad and fan system with finned-tube coils mounted downstream of the pads is used. The pads are typically filled with a fibrous material. Condenser coolfng water drips vertically along the fibers while alr flows horizontally through the pad. The air is heated or cooled depending on the ratio of sensible- to latent-heat transfer. The cooled water is collected at the bottom of the pad and returned to the condenser.

Warm water from the condenser can also be pumped through the finnedtube coils. The air coming from the pads is heated and dried by the addition of sensible heat from the fins. By varying the air flow rate and the relative amounts of water pumped through the pads and coils, the temperature and humidity of the air entering the greenhouse can be adjusted. This system can be used for summer cooling and winter heating. Heated or cooled air can be allowed to pass through the house and out the other end through exhaust fans. Air can also be recirculated through the attic during certain environmental conditions (e.g., cold weather).

These feasibility studies led to the construction of a small [6.1- by 14.6-m (20- by 48-ft)] Mylar experimental greenhouse at ORNL. The aspen fiber pads were fed with $40^{\circ} \mathrm{C}\left(105^{\circ} \mathrm{F}\right)$ water at a rate of 37.21 iters $/ \mathrm{m}$ (3 $\mathrm{gpm} / \mathrm{ft}$ ) of pad length from an air conditioning cooling tower. The

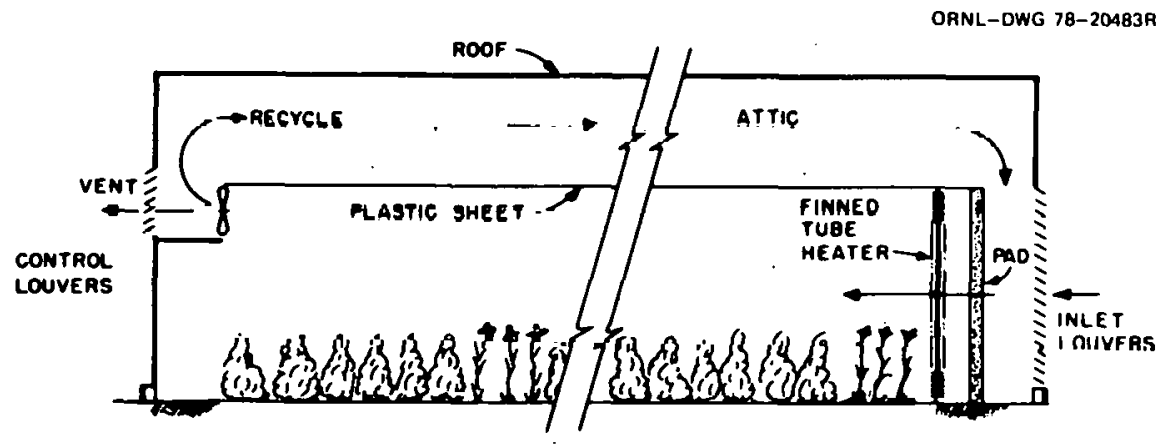

Fig. 1. Schematic of greenhouse heating and cooling system. 
greenhouse was operated from fall 1970 to summer 1971 to determine the operating characteristics of the pad and finned-tube system in the heating and cooling modes. Success in this experimental effort led to the joint waste heat greenhouse program with TVA.

ORNL has also analyzed the economic feasibility of heating greenhouses with power plant reject heat. Results from these studies indicate that, if condenser outlet temperatures of $27^{\circ} \mathrm{C}\left(80^{\circ} \mathrm{F}\right)$ or above are available, reject heat is the economic energy choice instead of fossil fuels. If the condenser outlet temperature falls below $27^{\circ} \mathrm{C}\left(80^{\circ} \mathrm{F}\right)$, feasibility of using reject heat depends on climate and the price of fossil fuels.' 


\section{DESIGN CONSIDERATIONS FOR THE BROWNS FERRY GREENHOUSE}

\subsection{General Considerations and Design Assumptions}

The successful operation of the Muscle Shoals facility led TVA to construct and operate a commercial-scale waste heat demonstration greenhouse at the Browns Ferry Nuclear Plant in northern Alabama. The power plant uses primarily open-mode cooling, and cooling water discharge temperatures range from about $18^{\circ} \mathrm{C}\left(65^{\circ} \mathrm{F}\right)$ in January to $43^{\circ} \mathrm{C}\left(110^{\circ} \mathrm{F}\right)$ in August. A $0.19-\mathrm{m}^{3} / \mathrm{s}(3000-\mathrm{gpm})$ delivery system, which is capable of supplying condenser cooling water from any of the three power production units, supplies warm water to a research and demonstration site located $\sim 610 \mathrm{~m}(2000 \mathrm{ft})$ outside the power plant security fence.

TVA and ORNL again cooperated in the design of the greenhouse, and the intial design was developed by ERL under contract with ORNL. The following design assumptions were made. The greenhouse was built with a total area of $\sim 0.2$ ha $(0.5$ acre), which was divided into three equal zones with intermediate walls for different horticultural environments and demonstration concepts. Zone I was "flush through" design, Zone II was a conventionally heated greenhouse environment not utilizing any waste heat from the power plant, and Zone III was a "closed mode" greenhouse with an environment similar to that maintained in the original Muscle Shoals facility. A schematic of the greenhouse is shown in Fig. 2.

The basic structure of the greenhouse was a commercially proven and available design with minimum modifications necessary to achieve the waste heat utilization objectives. The support hardware was commercially available materials with minimum modifications and proven component reliability. Design loads on the house were selected as follows:

\begin{tabular}{lc} 
& $\begin{array}{c}\text { Design loads } \\
{\left[\mathrm{Pa}\left(1 \mathrm{~b} / \mathrm{ft}^{2}\right)\right]}\end{array}$ \\
\cline { 2 - 2 } Rough live load downward & $239(5)$ \\
Rough live load upward (average) & $622(13)$ \\
Rough vegetation load & $239(5)$ \\
Wal1 wind load on windward side & $814(17)$ \\
Wall wind load on leeward side & $814(17)$ \\
Assumed soil pressure & $71,800(1,500)$
\end{tabular}




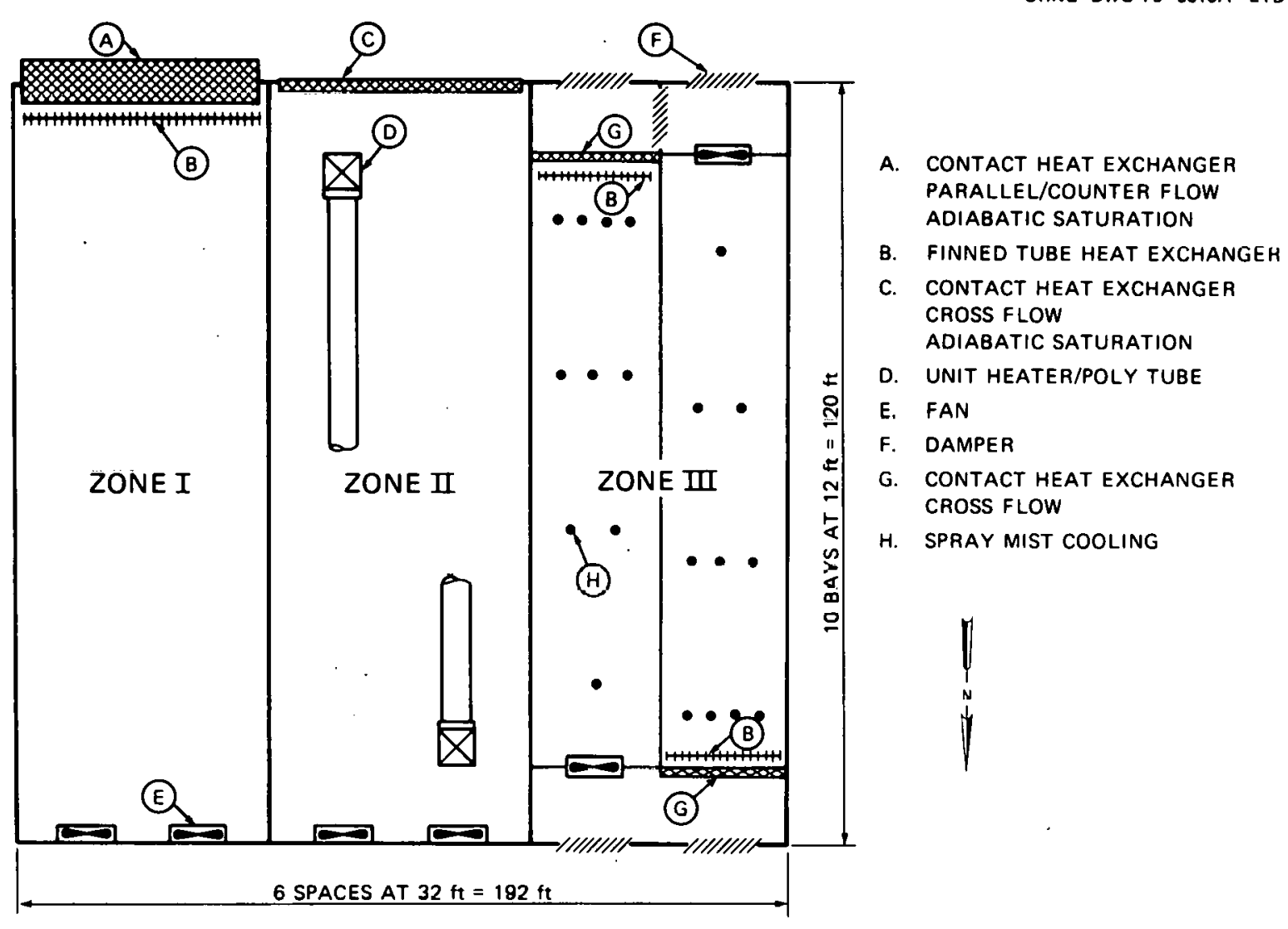

Fig. 2. Browns Ferry Greenhouse schematic.

The following climatic conditions were used as the design basis:

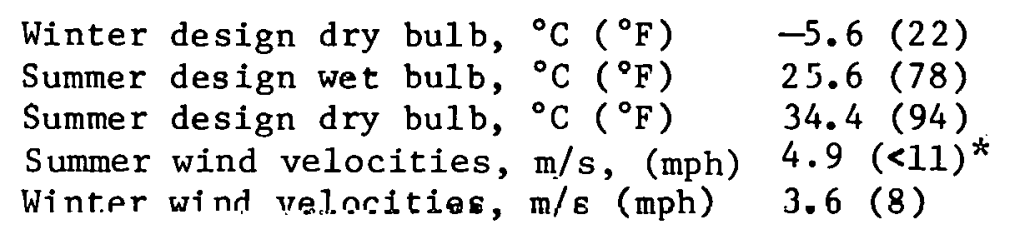

The air handling system shosen was of a variable capacity, with the maximum complete air change rate not less than 1 greenhouse volume/min.

In the original greenhouse location, little or no pumping was required for the waste heat water supply. The greenhouse was later relocated, and a significant investment in hoth piping and pumping became necessary to move the water from the power plant to the greenhouse site.

\footnotetext{
${ }^{*} 80 \%$ of the time.
} 
This is important because little or no economy of water usage is associated with the design ideas, particularly in Zone $I$. The assumption was made that there would be a virtually unlimited amount of available water with no economic advantage associated with its conservation or contained energy. This philosophy was retained even after the exact greenhouse 10cation was fixed.

The water supply to the greenhouse was condenser discharge water, and the water treatment used in the power plant was assumed compatible with commonly used piping materials. The water-supply temperatures used in the design analysis are shown in Table 1 . The minimum desired temperature in the environmentally controlled area was $15.6^{\circ} \mathrm{C}\left(60^{\circ} \mathrm{F}\right)$.

Table 1. Browns Ferry Nuclear Plant monthly average condenser discharge temperatures by $\left[{ }^{\circ} \mathrm{C}\left({ }^{\circ} \mathrm{F}\right)\right]$ mode

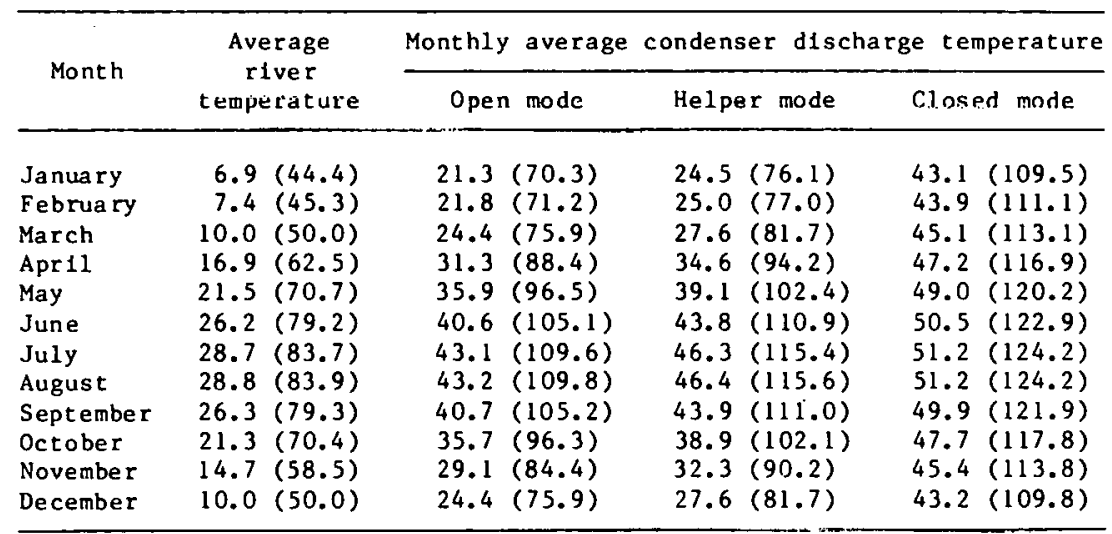

The cooling modes and techniques considered in the design included cross-flow adiabatic saturation, counter-flow adiabatic saturation, and spray mist evaporative cooling. The heating modes and techniques included liquified petroleum gas-fired unit heaters, contact heat exchangers, and finned-tube heat exchangers (with the last two using warm water from the power plant).

\subsubsection{Cooling techniques}

An evaporative cooling process, essentially one of constant wet bulb temperature, is rigorously considered to be an adiabatic saturation process because no net heat energy input or output is required. The sensible 
energy removed from the air, which causes its dry bulb temperature to drop, is replaced by latent energy in the form of an increased quantity of water vapor. Note that this evaporative cooling process is not free of all energy inputs. Considerable mechanical work can be required to move the air and water masses through a direct-contact medium. The supply of additional water to replace that lost to evaporation implies the transfer of some energy to or from the system if the water-supply temperature is not equal to the ambient wet bulb temperature. ${ }^{3}$

The measure of evaporative cooling performance is usually expressed in terms of effectiveness defined by Eq. (1):

$$
\ddot{n}=\frac{T_{d}-T_{p}}{T_{d}-T_{w}},
$$

where $n$ is the effectiveness usually expressed as percentage, $T_{d}$ is the ambient dry bulb temperature entering the cooler, $\mathrm{T}_{\mathrm{p}}$ is the dry bulb temperature of the air leaving the cooler, and $T_{W}$ is the ambient wet bulb temperature.

The process can be represented on a psychrometric chart (Fi.8. 3). In this case, the heavy line running from lower right to upper left defines an evaporative cooling effectiveness of $78 \%$ when expressed in either centigrade or Fahrenheit dimensions.

$$
\begin{aligned}
& n=\frac{35^{\circ} \mathrm{C}-23.3^{\circ} \mathrm{C}}{35^{\circ} \mathrm{C}-20.0^{\circ} \mathrm{C}} \\
& n=0.78,
\end{aligned}
$$

or

$$
\begin{aligned}
& n=\frac{95^{\circ} \mathrm{F}-74^{\circ} \mathrm{F}}{95^{\circ} \mathrm{F}-68^{\circ} \mathrm{F}} \\
& n=0.78 .
\end{aligned}
$$

Another way of expressing this effectiveness is to say that the air dry bulb temperature can be dropped by $78 \%$ of the wet bulb depression. 3 


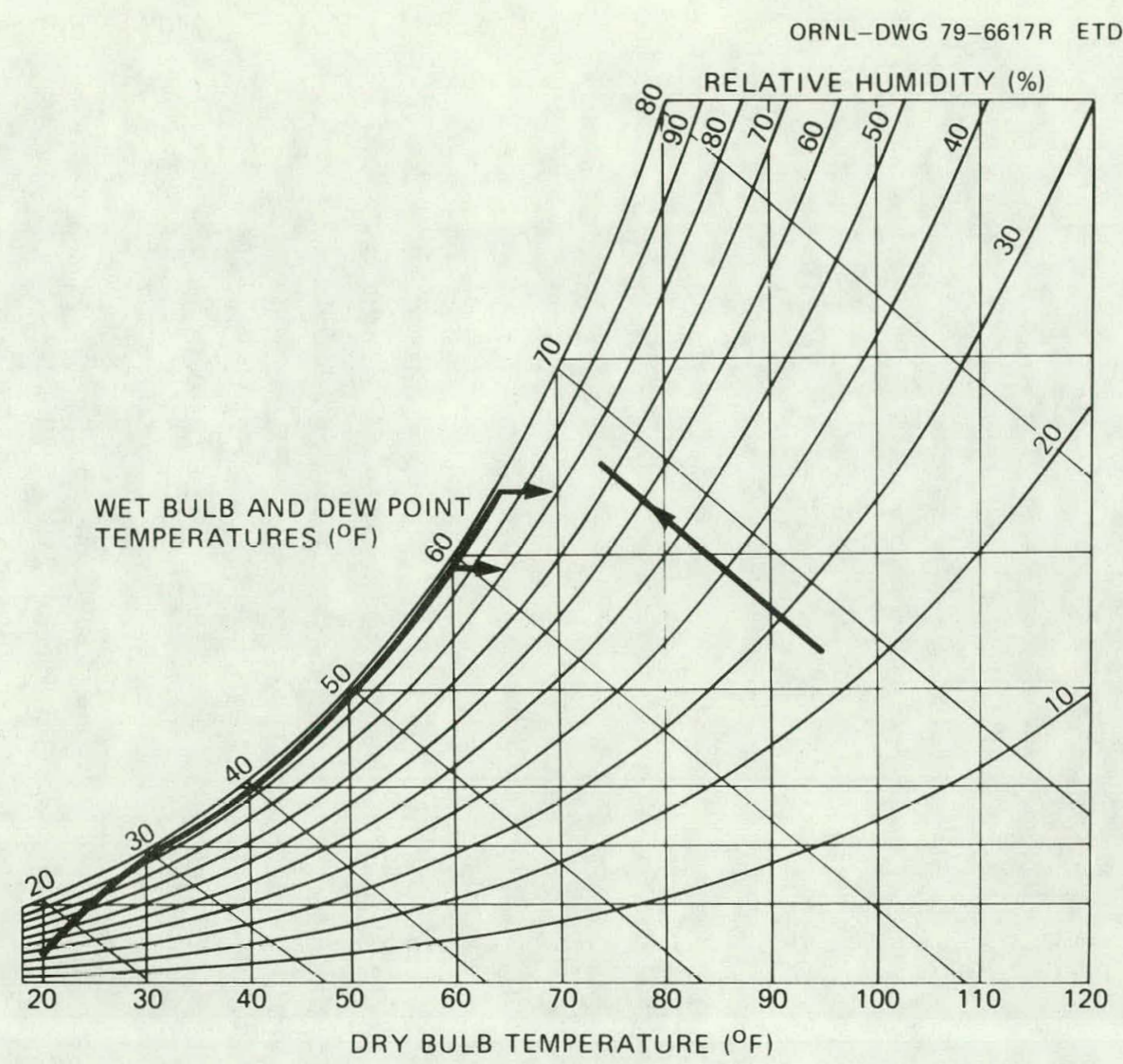

Fig. 3. Psychrometic chart for air and water vapor mixture.

Two materials have received fairly widespread use as evaporative cooling media: shredded aspen fibers and a corrugated cellulose material known as CELdek (a CELdek sample is shown in Fig. 4). Aspen, a low-cost material widely used in greenhouse, poultry barn, and commercial and residential applications, dominates the evaporative cooler media market. CELdek, a relatively new product in this application, has been successfully used in special cases.

CELdek was chosen as the evaporative cooling medium for the Browns Ferry Greenhouse. This decision was based on operating experience at the Muscle Shoals facility and on experimental work done at ORNL. ${ }^{1}$ This material has also been used by ERL in a number of other locations including the Arid Lands Research Center, Abu Dhabi; Kharg Environmental Farms, Kharg Island, Iran; Quechan Environmental Farms, Winterhaven, California; and Superior Farming Company, Tucson, Arizona. 


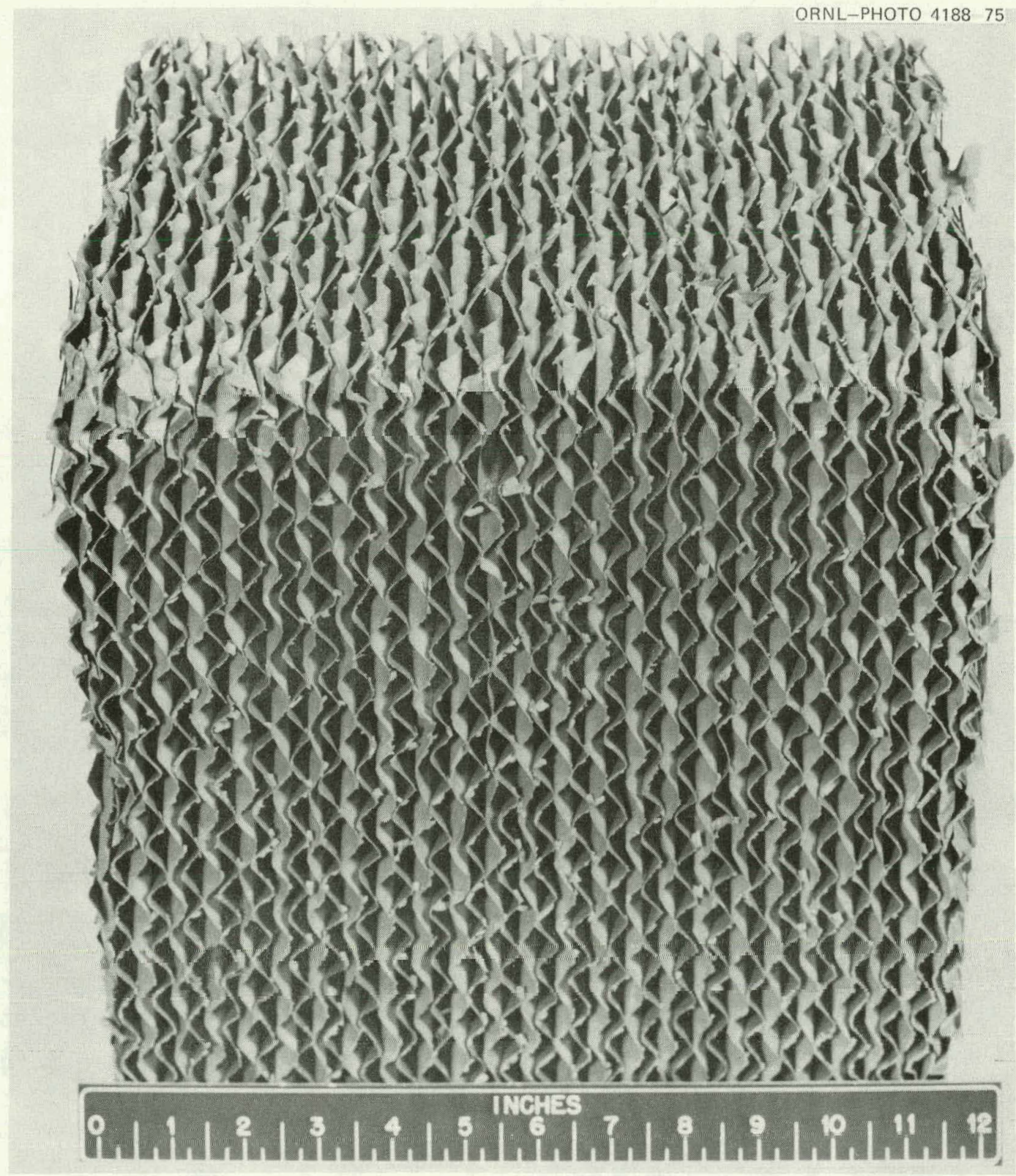

Fig. 4. CELdek sample.

Figure 5 shows the effectiveness and pressure-drop performance of both materials as functions of air velocity in cross-flow configuration. The aspen performance is shown as bands rather than lines because the typical greenhouse aspen installation cannot be maintained or even constructed with the same level of quality control that accompanies most CELdek installations. With time, the aspen material has a tendency to 
ORNL-DWG 79-6615 ETD

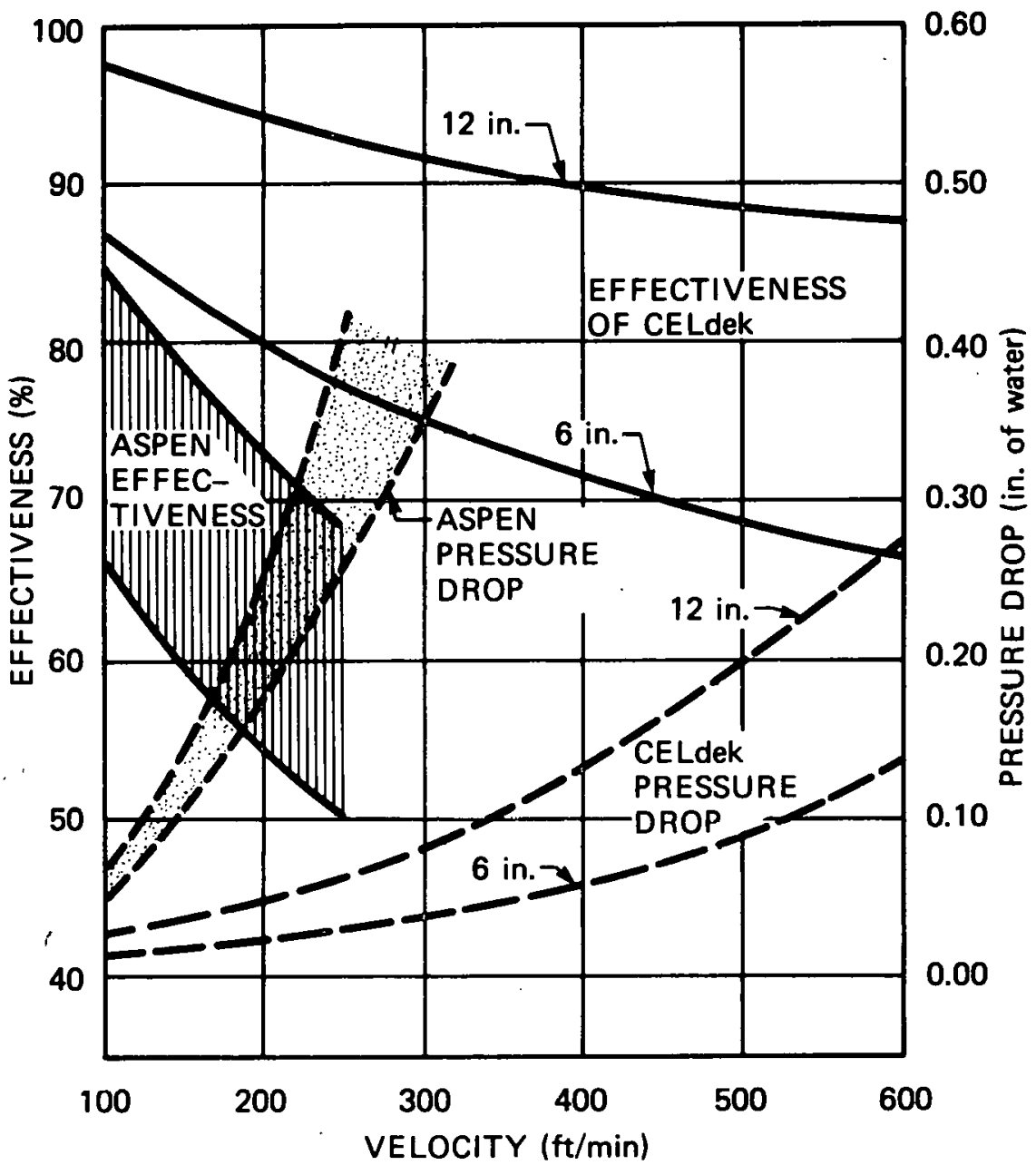

Fig. 5. Aspen and CELdek performance.

shift and move within its frame. When this shift occurs, holes open, allowing large quantities of air to bypass the water, which reduces both pressure drop and effectiveness. Experience has shown that the performance of CELdek is less subject to change after its initial installation and break-in period.

CELdek requires a higher water flow rate than aspen because there is more surface area to be kept wet per linear foot of wall, and the initial water distribution system is more critical because water can move through CELdek in only two dimensions. The continuous corrugated sheets do not permit sideways movement of the water. Thus, if any vertical plane does 
not receive water from the distribution system, that entire plane will be dry. Aspen fibers, which are more random and unstructured in their orientation, will permit water movement in all directions as influenced by gravity, wicking action, and air movement.

\subsubsection{Heating techniques}

Direct-contact heat-transfer surfaces are employed in greenhouse heating applications also. Referring again to Fig. 3, the dark line along the saturation curve represents the conditions of an airwater-vapor mixture as it moves through a contact heat-transfer surface wetted by a nonrecirculating warm water supply. This is a cooling-tower-associated process rather than an adiabatic saturation process. In the case of a greenhouse heating problem, the objective is not to cool water, as it is in a cooling tower, but rather to heat a1r. In any case, the thermodynamic procedure for analyzing either problem is the same; and the final water temperature, as well as the final air temperature, can be predicted. 3

The basic relation that describes this process is known as the Merkel Equation: ${ }^{4}$ :

$$
\frac{\mathrm{KaV}}{\mathrm{L}}-\int_{\mathrm{T}_{1}:}^{\mathrm{T}} \cdot \frac{\mathrm{C}_{\mathrm{p}} \mathrm{dT}}{\mathrm{l}_{\mathrm{S}}-\mathrm{h}_{\mathrm{a}}},
$$

where $K$ is a mass-transfer coefficient, a is the surface area of the heattransfer medium, $V$ is the volume of the heat-transfer medium, $L$ is the water flow rate, $\mathrm{T}_{\mathrm{H}}$ is the leaving water temperature, $\mathrm{T}_{2}$ ie the entering water temperature, $C_{p}$ is the sperific heat of air, dT is the incremental difference in water temperature, $h_{s}$ is the enthalpy of the air-watervapor mixture at saturated conditions of temperature $T_{p}, h_{a}$ is the air water-vapor enthalpy of the actual operation condition at temperature $t$, and $h_{s}-h_{a}$ is the driving force for energy transfer. ${ }^{3}$

This equation can be solved numerically by a "four-point Tchebychef Function." The results over a broad range of variables have been prepared by the Midwest Research Institute of Kansas City, Missouri, and are published. in a book known in the cooling tower trade as "The Blue Book." 5 


\subsection{Zone I Design}

Zone I in the greenhouse is the major contribution to new design technology. The use of very high liquid flow rates over a paralle1and/or counter-flow contact heat exchanger is very similar to the heat-transfer process used in conventional cooling towers. This idea was partially demonstrated at the University of Arizona facility in Puerto Penasco, Sonora, Mexico, in 1968 through $1970 .^{6}$

The $21-$ by $37-\mathrm{m}(70-$ by $120-\mathrm{ft})$ zone has a heat 1 oad of $\sim 109,600 \mathrm{~J} / \mathrm{s}$ $(374,000 \mathrm{Btu} / \mathrm{h})$ based on winter design conditions shown in Sect. 2.1. The heat-transfer surface area and air and water flow rates were designed to bring the air into the greenhouse at a temperature within about four degrees of the power plant discharge-water temperature.

The flush-through design uses large quantities of outside air that initially pass through a parallel-flow heat-exchanger surface. This heat exchanger is followed by a counter-flow section and a finned-tube heat exchanger, as shown in Fig. 6. Design conditions are shown in Table 2.

The heat-exchanger pads were deliberately oversized in this design to maintain adequate conservatism while investigating a new technical approach, to assure structural stability [the $0.3-\mathrm{m}$ (12-in.) CELdek material

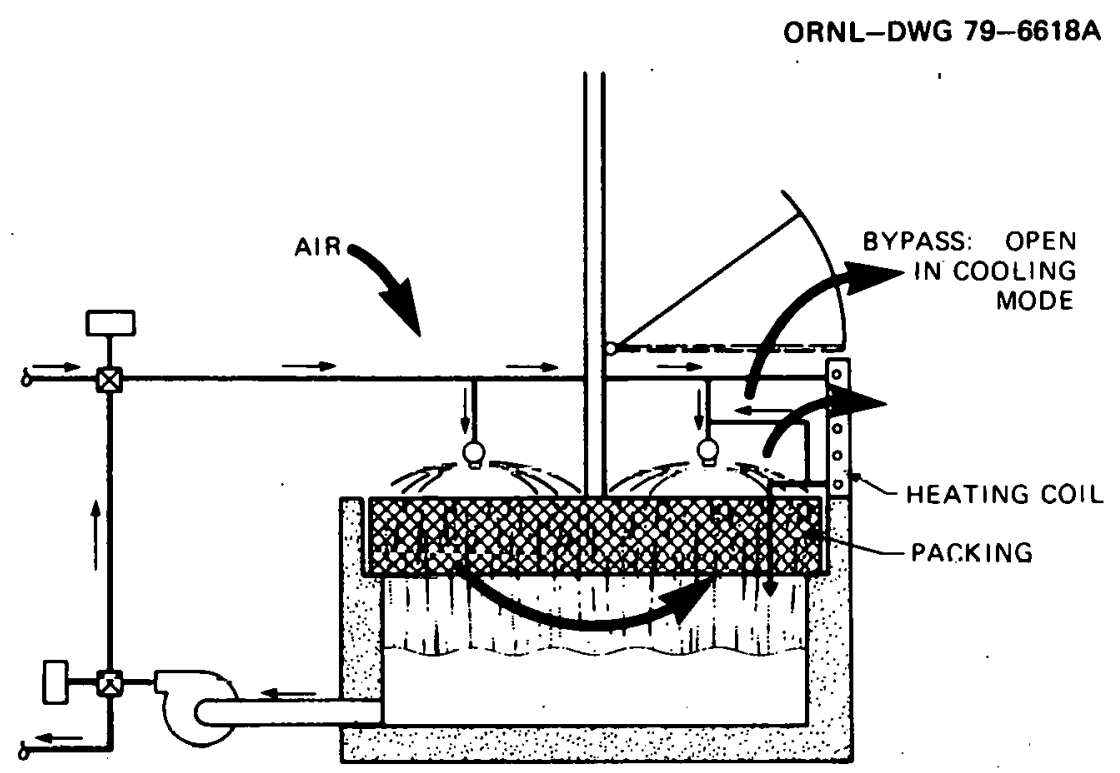

Fig. 6. Browns Ferry Greenhouse Zone I heat exchanger. 
Table 2. Zone I design conditions

Greenhouse module size, m ( $f t$ )

Airflow (winter), $\mathrm{m}^{3} / \mathrm{s}$ (scfm)

Fill volume, $\mathrm{m}^{3}\left(\mathrm{ft}^{3}\right)$

Fill face area, $\mathrm{m}^{2}\left(f t^{2}\right)$

Air face velocity, $\mathrm{m} / \mathrm{s}$ ( $\mathrm{fpm}$ )

Entering water temperature (minimum), ${ }^{\circ} \mathrm{C}$ ( ${ }^{\mathrm{F}} \mathrm{F}$ )

Entering water enthalpy, J/g (Btu/lb)

Entering air dry bulb temperature, ${ }^{\circ} \mathrm{C}\left({ }^{\circ} \mathrm{F}\right)$

Entering air wet bulb temperature, ${ }^{\circ} \mathrm{C}\left({ }^{\circ} \mathrm{F}\right)$

Entering air relative humidity, \%

Conductive heat losses, J/s $(\mathrm{Btu} / \mathrm{h})$

Water flow, total, liters/s (gpm)

Parallel-flow contact heat exchanger

Water flow, liters/s (gpm)

Air pressure drop, $\mathrm{Pa}$ (in. $\mathrm{H}_{2} \mathrm{O}$ )

Entering air enthalpy, $\mathrm{J} / \mathrm{g}(\mathrm{Btu} / \mathrm{lb})$

Exiting air enthalpy, $\mathrm{J} / \mathrm{g}$ (Btu/lb).

Exiting water enthalpy, J/g (Btu/lb)

Exiting water temperature, ${ }^{\circ} \mathrm{C}\left({ }^{\circ} \mathrm{F}\right)$

Counter-fluw cuntact heat exchanger

Water flow, liters/s (gpm)

Air pressure drop, $\mathrm{Pa}$ (in. $\mathrm{H}_{2} \mathrm{O}$ )

Entering air enthalpy, $\mathrm{J} / \mathrm{g}(\mathrm{Btu} / 1 \mathrm{~b})$

Exiting air enthalpy, J/g (Btu/lb)

Exiting water enthalpy, J/g (Btu/1b)

Exiting water temperature, ${ }^{\circ} \mathrm{C}\left({ }^{\circ} \mathrm{F}\right)$

Finned-tube heat exchanger

Water flow, liters/s (gpm)

Air pressure drop, $\mathrm{Pa}$ (in. $\mathrm{H}_{2} \mathrm{O}$ )

Entering air enthalpy $60^{\circ} \mathrm{F}, \mathrm{J} / \mathrm{g}(\mathrm{Btu} / \mathrm{lb})$

Exiting air enthalpy, $\mathrm{J} / \mathrm{g}$ (Btu/lb)

Exiting water enthalpy, $\mathrm{J} / \mathrm{g}(\mathrm{Btu} / 1 \mathrm{~b})$

Exiting water temperature, ${ }^{\circ} \mathrm{C}\left({ }^{\circ} \mathrm{F}\right)$

Exiting air dry bulb temperature, ${ }^{\circ} \mathrm{C}\left({ }^{\circ} \mathrm{F}\right)$

Exiting air relative humidity, \%
21 by 36.5 ( 70 by 120 )

$10(21,000)$

$5.9(210)$

$19.5(210)$

$0.51(100)$

$21.1(\overline{7} 0)$

$88.5(38.05)$

$-5.56(22)$

-7.22 (19)

60

$109,600(374,000)$

$50.5(800)$

20.2 (320)

$3.73(0.015)$

$15.6(6.7)$

$48.1(20.7)$

$69.1(29.7)$

17.2 (63)

$20.2(320)$

$3.73(0.015)$

$48.1(20.7)$

67.4 (29)

$76.9(33.1)$

$18.9(66)$

$10.1(160)$

$12.4(0.05)$

67.4 (29)

$71.4(30.7)$

$83.7(36.0)$

$20(68)$

$21(70)$

80 
chosen requires fewer structural supports than the 0.15-m (6-in.) CELdek], and to allow for separate testing of the paralle1- and counter-flow sections. Each of these sections is sized to provide adequate heat-transfer surface to bring the air temperature up to $18^{\circ} \mathrm{C}\left(64^{\circ} \mathrm{F}\right)$ given $21^{\circ} \mathrm{C}\left(70^{\circ} \mathrm{F}\right)$ entering water. Additional testing of these sections, independent of each other, is suggested as a reference source for future designs.

The calculations for sizing the heat-exchanger pad were done with the techniques described in Sect. 2.1.2. Curves representing some properties of CELdek material are shown in Fig. 7, where L/G is the liquid flow rate divided by the gas flow rate. $\mathrm{KaV} / \mathrm{L}$ is a function of the heat-transfer medium and the liquid flow rate.

The chosen pads have a cooling effectiveness of $90 \%$ at a $2-\mathrm{m} / \mathrm{s}$ (400-f pm) face velocity. This was calculated with Eq. (1) described in Sect. 2.1.1.

A finned-tube heat exchanger was installed to add sensible heat and reduce the relative humidity of the air from 100 to $80 \%$. [Moisture

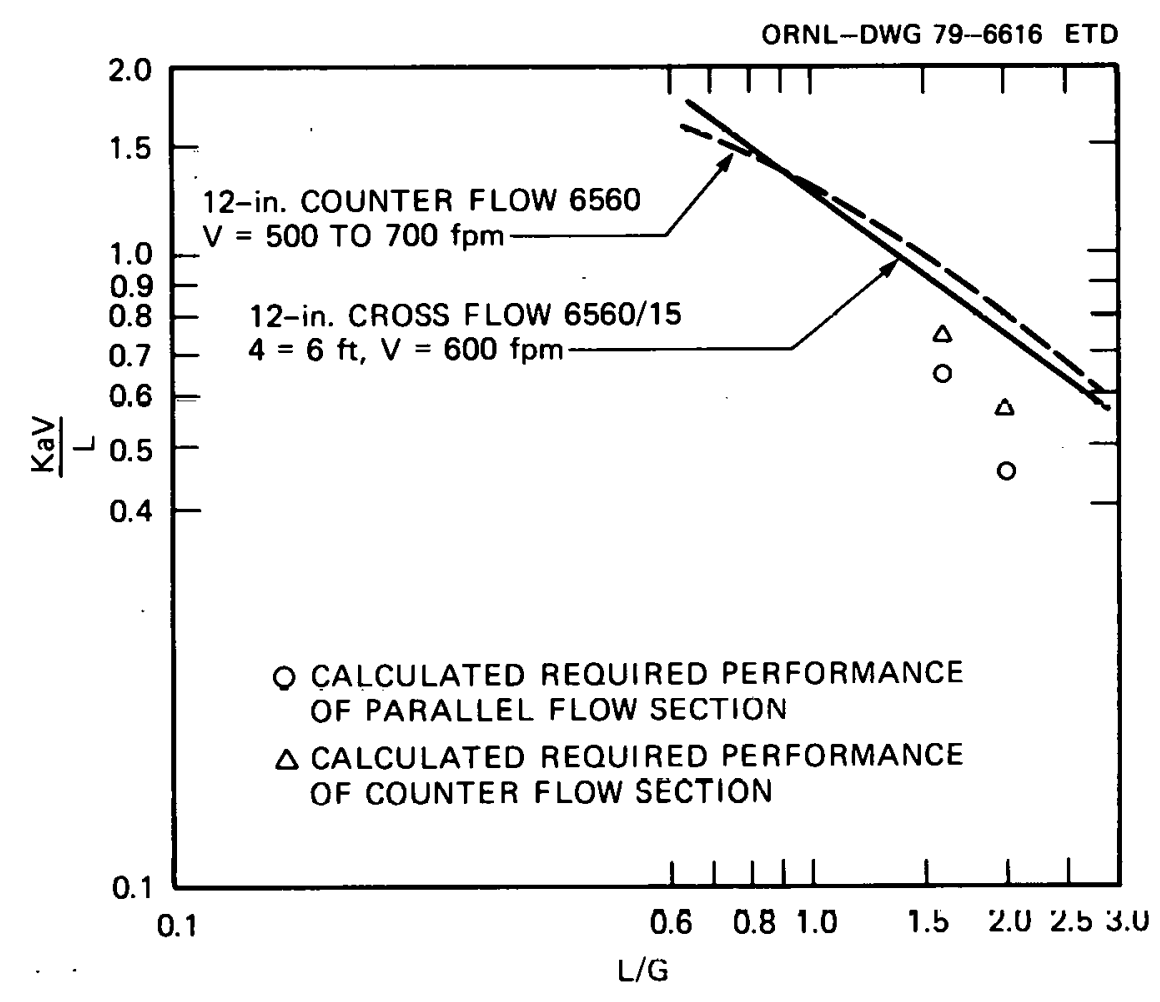

Fig. 7. Heat-exchanger pad sizing. 
carry-over problems made it difficult to demonstrate this total amount of relative humidity reduction if the second (counter-flow) section of the packing material was being used.] Four finned-tube heat exchangers were placed in Zone $I$. Each heat exchanger had a face area of $1.7 \mathrm{~m}^{2}\left(18 \mathrm{ft}^{2}\right)$ and a fin spacing of $5 \mathrm{fins} / \mathrm{cm}$ (12 fins/in.). One-pass coils were chosen.

A determination was made that, with slight compromises, the same air handling systems ( $f$ ans) could be used for all three zones. A $9.9-\mathrm{m}^{3} / \mathrm{s}$ $(21,000-c f m)$ fan was selected, and four fans were installed in each zone. From one to four of the fans could be used, depending on the operating mode and immediate needs of the environment. This capacity allows a summer air flow of $40 \mathrm{~m}^{3} / \mathrm{s}(84,000 \mathrm{cfm})$, which is equal to 1 air change/min.

\subsection{Zone II Design}

Zone II was designed as a traditional greenhouse for operational comparisons with the zones using waste heat. The design heat load was calculated as $93,500 \mathrm{~J} / \mathrm{s}(319,000 \mathrm{Btu} / \mathrm{h})$ from conductive losses and 3,800 J/s $(13,000 \mathrm{Btu} / \mathrm{h})$ from infiltration for a total heat load of $97,300 \mathrm{~J} / \mathrm{s}$ $(332,000 \mathrm{Btu} / \mathrm{h})$. Two propane heaters, each with a capacity of $48,600 \mathrm{~J} / \mathrm{s}$ $(166,000 \mathrm{Btu} / \mathrm{h})$, were suspended from the ceiling. These heaters can provide $1.9 \mathrm{~m}^{3} / \mathrm{s}$ ( $4000 \mathrm{cfm}$ ) of air at temperatures ranging from 15.6 to $37.8^{\circ} \mathrm{C}\left(60\right.$ to $\left.100^{\circ} \mathrm{F}\right)$, depending on the outside air temperature.

A wall for conventional vertical evaporative cooling was installed to provide summer climate control. A CELdek pad $0.15 \mathrm{~m}$ ( 6 in.) thick by $1.2 \mathrm{~m}$ (48 in.) high by $21.3 \mathrm{~m}(70 \mathrm{ft}$ ) wide was chosen to be used in a cross-flow application (see Fig. 2). This pad has a $72 \%$ cooling effect1veness, with an air face velocity of $2 \mathrm{~m} / \mathrm{s}$ (400 fpm).

As in Zone 1, the four fans installed in Zone II are capable of supplying a $40-\mathrm{m}^{3} / \mathrm{s}(84,000-\mathrm{cfm})$ air flow rate (1 air change/min) for summer use.

\subsection{Zone. T.TT Design}

The third zone of the Browns Ferry Greenhouse was patterned after TVA's Muscle Shoals experimental greenhouse. In the Muscle Shoals application, air is recirculated through an "attic" formed by a double-walled 
roof. In Zone III of the Browns Ferry Greenhouse, the air is recirculated by placing a vertical wall down the center of the zone. Evaporative pads, finned-tube heat exchangers, fans, and adjustable louvers are located at each end (see Fig. 2).

During winter operation, the outside louvers are closed, and the air is recirculated with a temperature drop of $\sim 6^{\circ} \mathrm{C}\left(10^{\circ} \mathrm{F}\right)$ from one end of the zone to the other. During the summer months, the outside louvers are opened, and Zone III is operated in much the same manner as Zone I. The louvers can be partially opened at any time to permit some mixing of outside air with recirculated air.

The evaporative pads chosen for Zone III are 0.3-m (12-in.) CELdek in a cross-flow configuration. They are $11 \mathrm{~m}(35 \mathrm{ft})$ long and $1.2 \mathrm{~m}$ ( $4 \mathrm{ft}$ ) high at each end. Design data for each heating section are included in Table 3 .

The finned-tube heat exchangers, which are identical to those used in Zone I, were placed at each end. As in Zone I, the water flow through these heat exchangers is a variable portion of the total flow. To control erosion and velocity problems, each heat exchanger is limited to a maximum of 8.2 liters/s (130 gpm).

The combined heating capacity of the pads and the finned-tube arrangement is $58,600 \mathrm{~J} / \mathrm{s}(200,000 \mathrm{Btu} / \mathrm{h})$. 
Table 3. Zone III design conditions

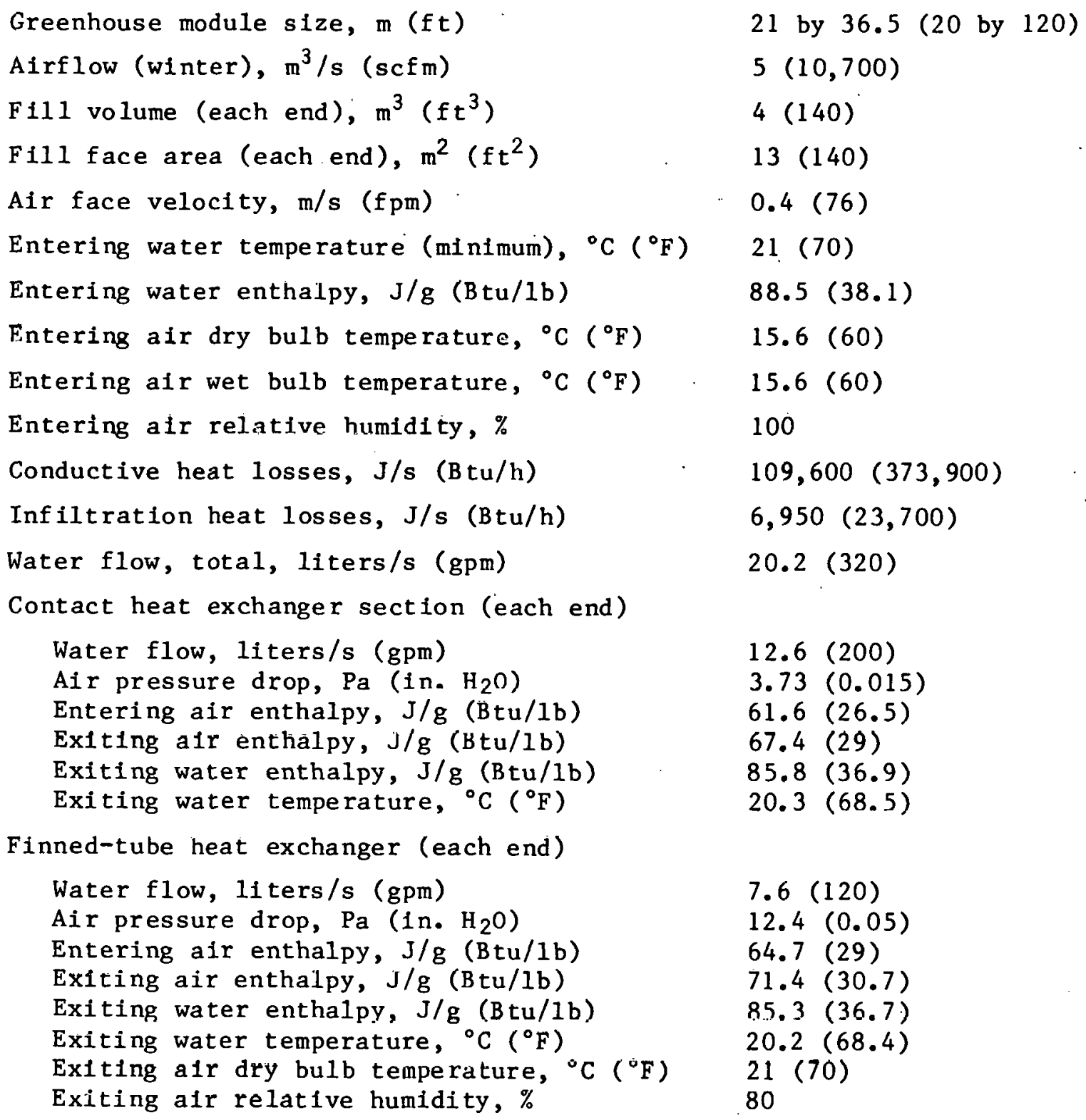




\section{ENVIRONMENTAL CONTROL SYSTEM PERFORMANCE}

\subsection{Initial Testing Period}

Construction of the greenhouse was completed in November 1978, and environmental control systems were placed in operation at that time. Mild weather was experienced until January 1979, when air and river temperatures were below normal. Waste heat temperatures at the greenhouse were then as low as $17^{\circ} \mathrm{C}\left(62^{\circ} \mathrm{F}\right)$, about $5^{\circ} \mathrm{C}\left(8^{\circ} \mathrm{F}\right)$ lower than had been expected.

Air temperatures within the greenhouse growing areas were measured during the colder periods of January and February to characterize the performance of the environmental control systems. Different air and water flow rates were used in the waste heat zones, and the effect on heating systems' performance was noted. Emphasis during this initial start-up period was placed on identifying any changes needed in the heating or other mechanical systems, developing operational guidelines and control sequences, and measuring temperatures achieved in the growing areas.

The heating performance of the environmental control systems is described in detail in the TVA Report Browns Ferry Waste Heat Greenhouse Environmental Control System Design. ${ }^{7}$ Presented below is a qualitative evaluation of each zone's. environmental control system.

\subsection{Performance of Zone I}

The 7nne. I waste heat environmental control system uses both parallel- and counter-flow air in a horizontal evaporative pad. During heating, outside air is continuously drawn through the evaporative-pad system, the finned-tube heat exchangers, and the growing area before being discharged at the north end of the zone.

Because water temperatures were lower than had been expected and a tomato crop had heen planted, efforts were made to operate the system for maximum heating. Ambient temperatures ranged from -12 to $-4^{\circ} \mathrm{C}$ (10 to $\left.25^{\circ} \mathrm{F}\right)$. : Waste heat temperatures at the spray nozzles during this time ranged from 15 to $20^{\circ} \mathrm{C}\left(59\right.$ to $\left.68^{\circ} \mathrm{F}\right)$, averaging $17^{\circ} \mathrm{C}\left(62^{\circ} \mathrm{F}\right)$. The average temperature in the growing area was maintained within about $5^{\circ} \mathrm{C}\left(9^{\circ} \mathrm{F}\right)$ of the incoming water temperature. However, temperatures at the growing area exit were well below those desired for the tomato crop. 
Although a measurable temperature increase occurred across the air side of the finned-tube heat exchangers, relative humidities within the growing area remained at saturation during all test periods. This was attributed to water droplets being pulled from the spray nozzles through the finned-tube heaters. Decreasing the water flow decreased the spray pulled through the exchanger but also lowered temperatures within the greenhouse.

The major problems encountered in Zone I were the low temperatures and high humidities in the growing area. The area remained noticeably foggy during all heating periods without significant solarinsolation. The spray nozzles and finned-tube heaters were frequently blocked by debris trom the warm river water. A dual basket strainer was installed in the warm water supply line to help alleviate this problem.

\subsection{Performance of Zone II.}

Optimum growing area temperatures were not maintained in the conventional zone during the colder periods of January and February. Nighttime temperatures as low as $8^{\circ} \mathrm{C}\left(46^{\circ} \mathrm{F}\right)$, which were partially caused by increased heat loss through the partition walls shared with the waste heat zones and by higher than expected infiltration losses, were recorded. However, when ambient temperatures were above $4^{\circ} \mathrm{C}\left(25^{\circ} \mathrm{F}\right)$, average growing area temperatures of about $13^{\circ} \mathrm{C}\left(56^{\circ} \mathrm{F}\right)$ or higher could be maintained.

\subsection{Performance of Zone III}

The Zone III waste heat envirnnmental control system used a vcrtical evaporative pad and finned-tube exchangers in conjunction with air recirculation during maximum heating. Full recirculation of air was needed when outside temperatures were below $7^{\circ} \mathrm{C}\left(45^{\circ} \mathrm{F}\right)$. As in Zone I, water temperatures available were lower than desired, and optimum growing area temperatures could not be achieved. Outdoor air and waste heat temperatures were the same as those noted for Zone $I$.

When all exterior vents were closed, average growing area temperatures were maintained at about $-4^{\circ} \mathrm{C}\left(25^{\circ} \mathrm{F}\right)$ below incoming water temperatures. Minimum growing area temperatures were slightly higher than in Zone I. 
With an increased air flow, very little difference was noted in the average growing area temperature, although the temperature distribution was more uniform. More water droplets were carried through the finnedtube exchanger at the higher air flow rate, making the growing area noticeably foggy.

Major problems encountered in this zone were also low growing area temperatures and high relative humidities. Average growing area temperatures were maintained within about $4^{\circ} \mathrm{C}\left(7^{\circ} \mathrm{F}\right)$ of the incoming water temperature, with minimum growing area temperatures about $7^{\circ} \mathrm{C}\left(12^{\circ} \mathrm{F}\right)$ below the water temperatures.

The warm water distribution holes were frequently obstructed and required cleaning on a biweekly basis. The same problems occurred with the finned-tube heaters as in Zone $I$. Ice formation in the exterior vent hinges 'was also a problem, especially during periods of high sunshine and below freezing temperatures. The vents were opened under these conditions to cool the growing area.

\subsection{Conclustons}

The two waste heat environmental control systems have performed near design expectations. These preliminary results indicate that either of the two systems tested is capable of maintaining greenhouse growing area temperatures within about $6^{\circ} \mathrm{C}\left(10^{\circ} \mathrm{F}\right)$ of incoming water temperatures in the range of 16 to $23^{\circ} \mathrm{C}\left(61\right.$ to $\left.73^{\circ} \mathrm{F}\right)$.

Heat losses through the greenhouse walls and roof were higher than expected, resulting in a larger than expected temperature drop through the greenhouse zones. An effort was made in February to locate and seal air leaks through the structure, and exhaust fans not used for heating were covered.

Minimum temperature for tomato production $\left[15.6^{\circ} \mathrm{C}\left(60^{\circ} \mathrm{F}\right)\right]$ cannot be maintained with the waste heat control systems when the warm water supply temperature is lower than about $21^{\circ} \mathrm{C}\left(70^{\circ} \mathrm{F}\right)$. However, the environments provided by these systems with cooler water should be suitable for crops with lower minimum temperature requirements. 


\section{REFERENCES}

1. W. K. Furlong, Physical Characterization of CELdek Material in a Simulated Greenhouse Environment, ORNL/TM-4815 (October 1975).

2. M. Olszewsk1, "Economic Aspects of Using Power Plant Reject Heat for Greenhouse Heating," presented at the International Symposium on Controlled Environment Agriculture, Tucson, Arizona, Apr. 7-8, 1977.

3. Neal Hicks, Proceedings - An Intermational Symposium on Controlled Environment Agriculture, Tucson, Arizona, Apr. 7-8, 1977.

4. D. Q. Kern, Process Heat Transfer, McGraw-Hill Book Company, New York, 1950.

5. Cooling Tower Institute, Cooling Tower Performance Curves, Houston, Texas.

6. Merle H. Jenson and Handy M. Eisa, Controlled Environment Vegetable Production: Results of Prials at Puerto Penasco, Mexico, 1968-1970, Environmental Research Laboratory, University of Arizona, Tucson, 1972.

7. R. S. Pile et al., Browns Ferry Waste Heat Greenhouse Environmental Control System Design, Tennessee Valley Authority, to be published. 
ORNL/TM-7167

\section{Internal Distribution}

1. T. D. Anderson

2. S. Baron

3. S. E. Beall

4. T. E. Cole

5. W. B. Cottrel1

6. C. C. Coutant

7. J. F. Ha rvey

8. R. F. Hibbs

9. H. W. Hoffman

10. D. Jared

11. 0. H. Klepper

12. R. E. MacPherson

13-37. M. 01szewski
38. H. Postma

39. S. A. Reed

40. J. L. Rich

41. D. $S \cot t$

42. M. J. Skinner

43. I. Spiewak

44-68. T. K. Stova11

69. H. E. Trammel1

70. D. B. Trauger

71-72. Central Research Library

73. Document Reference Section

74-75. Laboratory Records Department

76. Laboratory Records, ORNL RC

\section{External Distribution}

77. Marty Adler, Oak Ridge Chamber of Commerce, 1400 Oak Ridge Turnpike, Oak Ridge, TN 37830

78. Gary Ashely, Northern States Power Company, 414 Nicollet Mall, Minneapolis, MN 55401

79. H. W. Behrman, DOE, ORO

80. John A. Belding, Assistant Director, Division of Conservation Research and Technology, DOE, Washington, DC 20545

81. Richard H. Bleiden, Blomass, Ocean \& Wind Systems, Division of Solar Energy, DOE, Washington, DC 20545

82. Edward Bryan, National Sclence Foundation, $1800 \mathrm{G} \mathrm{St.,} \mathrm{NW,}$ Washington, DC 20545

83. William R. Cherry, Chief, Agriculture and Process Heat Branch, Division of Solar Energy, DOE, Washington, DC 20545

84. Bart Chezar, Power Authority of New York, 10 Colorado Circle, New York, NY 10019

85. Dr. Isaac J. Crumbley, Division of Sclence and Math, P. 0. Box 5800, Ft. Valley, GA 31030

86. L. F. Diaz, Ca1 Recovery Systems, 160 Broadway, Suite 200, Richmond, CA 94804

87-97. Environmental Research Laboratory, University of Arizona, Tucson International Airport, Tucson, AZ 85706

98. Edward Gaines, Vermont Yankee Nuclear Power Corp., 77 Grove St., Rutland, VT 05701

99. Bruce Godfriaux, Public Service Electric \& Gas Company, Room 12329, Newark, NJ 07101

100. Marvin Gunn, Division of Power Systems, Energy Technology Group, DOE, Washington, DC 20545 
101. Doug Harvey, Assistant Director for Industrial Systems, Division of Industrial Energy Conservation, DOE, Washington, DC 20545

102. Heyward D. Hamilton, Division of Biomedical and Environmental Research, DOE, Washington, DC 20545

103. F. Incropera, Department of Mechanical Engineering, Purdue University, West Lafayette, IN 47907

104-107. Ira Helms, DOE, Advanced Systems and Materials Products Division, Washington, DC 20545

108. D. R. Israel, Office of Energy Research, DOE, Washington, DC 20545

109-111. Joe Kelly, Southern California Edison, P. 0. Box 800, 2244 Walnut Grove Ave., Rosemead, CA 91770

112. D. Linz, DOE, ORO

113. Leslie Nieves, Battelle Northwest Laboratory, Box 999, Richland, WA Yy352

114-138. Bob Pile, TVA, Muscle Shoals, AL 35660

139. Don Price, Division of Industrial Energy Conservation, DOE, 20 Macoaohusette Ave., Washington, DC 20515

140. W. F. Savage, DOE, Advanced Systems and Materials Products Division, Washington, DC 20545

141-143. Robert Seat, Hines Nurseries, P. 0. Box 11208, Santa Ana, CA 92711

144. J. S. Suffern, 126 Everest Circle, Oak R1dge, TN 37830

145. G. J. Trezek, Department of Mechanical Engineering, University of California, Berkeley, Berkeley, CA 94720

146-147. Director, Office of Fuel Cycle Evaluation, Nuclear Energy Programs, DOE, Washington, DC 20545

148. Director, Reactor Division, DOE, ORO

149. Office of Assistant Manager, Energy Research and Development, DOE, ORO

150-176. Technical Information Center, DOE 